УДК 303.82:005:001.3

JEL Classification:

O32, O38, I28
S.M. POREV, PhD (Engineering), laboratory head, Institute of Magnetism of the National Academy of Sciences of Ukraine and the Ministry of Education and Science of Ukraine, e-mail: sn_porev@ukr.net

\title{
WHAT HAS THE UKRAINIAN LEGISLATION PROPOSED TO MANAGEMENT FOR RESEARCH QUALITY?
}

Keywords:

(C) S.M. POREV, 2018
This article represents the study of Ukrainian legislative documents in order to define, how they promote scientific quality, performance and excellence. The research management problem is defined as a limitation to use direct research and knowledge management and a reason for implementation of indirect criteria. The study shows that aims, principles and requirements on scientific quality, excellence and performance as motivated proposals mainly absent in Ukrainian legislation and they have no systemic context for realization. It is noted, that an operative use of scientific degrees and academic titles as criteria of scientific quality leads to the weakness of policy, because they mainly represent the social status and qualification. Another weaken position in legislation is an absence of requirements for research assessment of individual scientists in order to stimulate research excellence and competition between them. The main result is that socioeconomic transformations may damage the unity of research policy, legislation and management and change the values of cognitive and creative activities.

research management, knowledge creation, science legislation, bibliometric indicators, scientific degrees, academic titles, quality, excellence, performance.

Formulation of the problem generally. Effective scientific and innovation policy and management should lead to a highly developed knowledge society. Ukrainian science and innovation system since Independence is under pressure of various economic, social and political factors, but whether the science and innovation public policy and management meet the requirements of the country development?

The study will show how the norms of R\&D have been distorted in the country's legislation, where academic elites are forced to fight with the purpose to maintain their position as a middle class, when there are not enough clearly defined 
requirements of the state and economic incentives in order to obtain and use high scientific results.

As experience suggests [8], in a country with socioeconomic deformations could arose situations in which access to funding and preferences don't strongly connected with scientific and educational excellence or performance. Communities and individuals always search an optimal and a simple way to resources. We have a reason to think [8] that in some cases scientific results and performance, thanks to the legislation, may be substituted by scientific degrees and academic titles (referred to hereinafter as D\&T).

There are many useful propositions of domestic R\&D managers were not accepted, ignored or distorted [8], but, as well known, «no prophet is accepted in his own country». Important events were presentations and publications of studies and propositions worked out by the independent panel of Horizon 2020 Policy Support Facility (PSF) [15]. However, the recommendations of the PSF panel may remain unfulfilled. There are at least two reasons. First, the reform will be carried out by persons and institutions that are not always interested in them, because the existing science and innovation system was created by their efforts. Second, the reforms should be realized in context of current laws, resolutions and other policy and management documents, which often are contrary to the recommendations. Possibly, managers of leading Ukrainian universities and research institutions often stimulate R\&D more initiatively by use of good practice and deep understanding, than according to the letter and the spirit of the regulations and standards.

The problem in general terms is to study how Ukrainian science policy and legislation directs $R \& D$ management to excellence and performance.

Review of recent research and publications. Ukrainian science and innovation system is in development and it save the perspectives to be competitive. S. Illiashenko and N. Illiashenko show [3] that Ukraine has considerable potential for innovation growth in the fourth industrial revolution. But it is noted [8], that R\&D indicators are less optimistic.

According to Table 1, the last two decades Ukrainian science showed a growing number of persons with candidate ( $\mathrm{PhD}$ level) and doctor degrees, but there is a gradual decrease of publications and citations in Scopus journals in comparison with other countries.

No doubts, $R \& D$ performance strongly connected with financing. We think, it is useful to compare the gross expenditure on $R \& D$ in purchasing power parity (PPP) US\$ per capita for East European countries by UNESCO statistics [27].

The gross expenditure on R\&D in PPP per capita (Table 2) shows the essence of science stagnation in Ukraine in the era, where other countries create knowledge economies.

A detailed analysis of the Ukrainian science and innovation legislation in 2011 provided by the group of Ukrainian and European experts showed the incompleteness of legislative and regulatory instruments for state target programs [16, p. 62]. 
As the United Nations review [28] shows, the current Ukrainian science and technology inefficient, R\&D excellence criteria are not widespread, activities neither contributing to the local economy nor to world science. UN review discussed $\mathrm{R} \& \mathrm{D}$ performance indicators but did not study the role of Ukrainian legislation to provide research excellence.

The PSF panel of Horizon 2020 defined thirty recommendations and seven policy messages to the Ukrainian government. As noted [15, p. 9]: «R\&D in Ukraine should be based on «excellence» in terms of academic world-class science and on «excellent science for innovation». According to Background report [24, p. 5], «one can observe a low share and negative trend of Ukraine's most cited publications worldwide as $\%$ of total scientific publications of Ukraine, a very low level of public-private publications and a rather low but steadily increasing level in international scientific co-publications».

It is also usual to define scientific excellence in terms of scientometric and bibliometric indicators. But as L. Bornmann and H.-D. Daniel show [13], «the probability of being cited depends on many factors that do not have to do with the accepted conventions of scholarly publishing». According to R. Tijssen [25], «the significance of bibliometric data should not be overstated. They are probably more

Table 1. Rank of Ukraine among other countries by publications and citations in Scopus and persons with scientific degrees in Ukraine

\begin{tabular}{|l|r|r|r|r|r|r|r|}
\hline & 1996 & 1999 & 2002 & \multicolumn{1}{|c|}{2005} & 2008 & 2011 & 2013 \\
\hline Rank by citations & 40 & 39 & 42 & 42 & 47 & 47 & 49 \\
Number of citations & 30248 & 43137 & 41183 & 50041 & 45314 & 39343 & 21796 \\
Rank by publications & 26 & 28 & 32 & 37 & 42 & 45 & 45 \\
Number of publications & 5682 & 5873 & 6161 & 7343 & 7184 & 8268 & 9868 \\
Doctors of science & 9974 & 10233 & 11008 & 12014 & 13423 & 14895 & 16450 \\
Candidates of science & 58132 & 59547 & 62673 & 68291 & 77763 & 84979 & 90113 \\
\hline
\end{tabular}

Source: data on persons with scientific degrees in Ukraine [7]; data publications and citations in Scopus [23].

Table 2. GERD in PPP\$ (in constant prices of 2005) per capita

\begin{tabular}{|l|r|r|r|r|r|r|}
\hline & \multicolumn{1}{|c|}{1999} & \multicolumn{1}{c|}{2002} & \multicolumn{1}{c|}{2005} & \multicolumn{1}{c|}{2008} & \multicolumn{1}{c|}{2011} & \multicolumn{1}{c|}{2014} \\
\hline Czech Republic & 185.05 & 212.48 & 260.44 & 314.90 & 387.52 & 498.35 \\
Hungary & 89.07 & 148.76 & 160.03 & 179.98 & 210.61 & 253.14 \\
Poland & 77.98 & 67.80 & 77.54 & 97.62 & 134.67 & 180.32 \\
Turkey & 43.97 & 50.56 & 68.04 & 90.70 & 116.24 & 141.45 \\
Romania & 26.76 & 29.51 & 38.86 & 70.06 & 58.41 & 49.76 \\
Ukraine & 39.19 & 50.42 & 76.11 & 66.36 & 54.68 & 46.07 \\
\hline
\end{tabular}

Source: [27]. 
useful as tool for structuring interactive assessment processes than being an independent conclusive basis for rational action».

The bibliometric indicators are important as auxiliary for ex post peer review. But citation measures have restricted usefulness for research management, because the high citation rank of previous work is not a guarantee for future good results. Also, there is no reason, why ten citation always better than five ones. It should be noted, that a benchmarking analysis of research excellence ex post is of limited value for $\mathrm{R} \& \mathrm{D}$ management.

There is considerable disparity across EU countries in terms of research excellence and innovation performance and that's why a «Stairway to Excellence» project was introduced. As noted in a Poland report as the part of the project documents (K. Klincewicz [18]), this project was aimed at promoting excellence research and innovation in all regions and the EU and focused on assistance to regions and countries that joined the EU since 2004.

It is also may be fruitful for Ukrainian R\&D policy an idea of «Responsible Research and Innovation» (RRI), that, as A. Rip underlined [22], evolved from a little-known phrase to an issue in the Horizon 2020 Program. According to R. von Schomberg [29], RRI defined as a process by which societal actors and innovators become mutually responsive.

It should be noted that today is not only a science «in the strict sense» needs legislative stimulation. Concept of «Mode 2» knowledge production defined in publications of H. Nowotny, P. Scott and M. Gibbons [21] is not epistemologically sound but very useful in the aspects of «social robustness» and as a cooperation of society for common responsibility, and as a tool of «research in context of application», which join more closely research with innovation. The concept of «Mode 2» is also leads the R\&D from ideals to obtain truth and objectivity in Science to solving problems in wide world of Practice, in some sense, from excellence to performance.

It is widely accepted, that $\mathrm{R} \& \mathrm{D}$ aims, values and results could be considered in terms of excellence and performance, but in general understanding knowledge patterns are incomparable or incommensurable (T. Kuhn, 1982; R. Chang, 1997) [14; 19]. We can compare different patterns of knowledge only in order to define which of them more «progressive», more competitive than other. Moreover, as I. Lakatos notes [20, p. 46-47], «sophisticated falsificationism is that it replaces the concept of theory $\langle\ldots\rangle$ by the concept of series of theories», and such series he called «a research programme». So, if we compare smaller patterns of knowledge, than research programs, this is already a certain approximation.

The R\&D and they management in a social world has economic purposes and common human values, but the main output - new knowledge and understanding of scientist - is subjective by the definition of knowledge as justified true belief [26]. As known, scientific knowledge is more than true belief, because it is created, justified or falsified by special «scientific methods», while there is no method to guarantee creation of the «best» knowledge. Nevertheless, policy and 
management should find the way to $\mathrm{R} \& \mathrm{D}$ excellence and high performance. The contemporary concepts of the «Stairway to Excellence» [18], the «Responsible Research and Innovation» [29] in context of «Mode 2» knowledge production [21] etc. should be translated into real R\&D management mechanisms. There are essential needs to provide policy, legislation and management tools for R\&D excellence and performance, especially in the case of Ukrainian realities.

The unresolved issues of previous studies are how Ukraine defines the main aspects of R\&D quality, excellence and performance in its legislation, and how ones should be defined in such «country in transition» and converted into management mechanisms.

The objective of the article is to study how Ukrainian science policy legal and regulatory documents present the needs of R\&D quality, excellence and performance in aims, principles, requirements, tasks and norms, and what should be done in order to obtain better solutions for research policy and management.

Results. If the R\&D management aimed at excellence and high performance of acquired new knowledge, it should use a methodology to compare the levels of these qualities. But if the outputs of research, some criteria an indicators of knowledge quality could be incomparable or incommensurable $[14 ; 19]$ due to the appraisal problem (demarcation problem) [20, p. 168], this defines a limit of R\&D management to stimulate excellence and performance of created knowledge. This could be called as research (or research and development) management problem. According to a main sense of the problem, there is no the best management act to create excellent knowledge, because there is no the best $R \& D$ result, but only temporary better competing one. The problem represents the fact, that at a «first level» of scientific knowledge (theories, descriptions, explanations, facts and propositions etc.) epistemological difficulties arise. There is no single answer to the question, can we consider some proposition better than already known. As I. Lakatos notes [20, p. 1], «thus a statement may be pseudoscientific even if it is eminently 'plausible' and everybody believes in it, and it may be scientifically valuable even if it is unbelievable and nobody believes in it. A theory may even be of supreme scientific value even if no one understands it, let alone believes it».

Difficulty to manage the research at the level of knowledge leaves room to create conditions for free competition of scientific proposals and academic debates. But the absence of direct research management propositions lead to domination of other social and economic influences, which can have positive or negative effects. We should have definable aims and indicators of research output in order to manage it.

It is possible to define the levels of R\&D management and objects. At the first level researcher «manage» his/her own actions not only for cognitive output, but in order to obtain social and economic results. At the second level knowledge (as subjective justified true belief) could be presented as information to inform others: this is the level of publications. At this level it is possible to manipulate the publication forms by assignment of presence and volume of its functional parts. The third 
level may include the quantitative indexes of publications and citations. It could be defined the fourth level, which presents D\&T and other possible forms of scientific merit recognition. The second, third and fourth levels more open for management and this gives an opportunity to impact on research quality and performance, but indirectly.

It should be noted, that $\mathrm{R} \& \mathrm{D}$ is individual and joint cognitive and socioeconomic activity, all aspects of which should be balanced in order to be effective. However, if the country's economy is constantly on the brink of crisis, as it is in Ukraine, and the needs of scientists as middle-class representatives are not provided, the scientific community can weaken the requirements of a rigid link between knowledge quality, scientific publications and D\&T and norms of scientific legislation will not guarantee their quality.

In order to study how Ukrainian legislation regulates R\&D activity we should consider the Law of Ukraine «On Scientific and Scientific-Technical Activity» [2] (LoSSTA).

The Horizon 2020 PSF panel reasonably noted [15, p. 8], that the reforms are «triggered by the new Law», but there is a great deal of skepticism about its implementation [15, p. 22]. The PSF panel not criticized the facts of absence of $\mathrm{R} \& \mathrm{D}$ excellence and performance requirements in the LoSSTA, but it advises «to develop a cross-governmental Research and Innovation Strategy and corresponding instruments» $[15$, p. 13].

We can show, that some regulations of this law far from the needs to reform R\&D.

It should be noted, that the LoSSTA used concepts of basic and applied research and experimental development, but factually, the definitions in the LoSSTA add to science the activities, which belong to more wide practice [8].

The LoSSTA defines «a scientist» and «a scientific worker» as the main subjects of scientific and scientific-technical activities, where the scientist carries out fundamental and/or applied scientific research and obtains scientific and/or scientific-technical results. Emphasis on results in the definition is important, and the scientist, it may be said, obtains them in principle, but it is not obliged to receive ones. There are no other clarifications regarding the quality of the results. According to the Article 6 [2], a scientific worker has the obligations to conduct R\&D according to agreements or contracts, to publish results etc., but he or she has no direct obligations to obtain $R \& D$ results and as regard to their quality.

Scientific institutions are also defined as the subjects of scientific and scientific-technical activities [2]. According to the «Typical contract», approved by the Cabinet of Ministers of Ukraine [12], a director of a scientific institution should to ensure effective scientific, technical and innovation activities and to provide competitive results. According to the Article 7 of the LoSSTA [2], at the public scientific institution can be established the Supervisory board with the purpose of independent assessment of scientific performance.

Quality and effectiveness of scientific and scientific-technical activity should be evaluated by a state attestation of the scientific institutions (Article 11). The 
state attestation commissions should use scientometric and other indicators of the international peer review. According to the LoSSTA [2], the results of the state attestation could be used as the reason for sanctions to the director and for considering a matter of reorganization or liquidation of the institution. The state attestation could be used as a part of a performance-based funding system [17], but additional facilities and stronger peer review are need.

An attestation of scientific workers (Article 29) is carried out to assess their professional skills and encouraging its increase and in order to evaluate their performance. This attestation can be a tool for increasing of $R \& D$ excellence and performance if these tasks were defined and encouraged. But the LoSSTA does not define effective mechanisms for this attestation.

According to the Article 36, a salary of a scientific worker should provide sufficient conditions of its effective creative activity [2]. While additional payments for workers with $D \& T$ were determined, there are no direct support of $R \& D$ quality and excellence.

It is clear, that if the aims, principles, requirements and tasks of R\&D policy are defined in a certain legislative document, they should lead to results quality, excellence and performance and should be a base for effective management. According to the Article 2 [2], the purposes of the Law include «creation of conditions to improve the efficiency of research» only as general declaration without propositions, how and what conditions could be created. The State should provide conditions for the development and effective use of scientific potential, and among the objectives of public policy is to achieve «a high level of science and technique development» (Article 45) [2]. But there were no directly defined principles and tasks of the State policy (Articles 2, 45, 46) to ensure high quality results of R\&D, their excellence and performance.

The LoSSTA presents the National Research Foundation which should focus its funding on grants. As proposed by PSF panel, «Competitive research funding should gain relevance to reach $40 \%$ by 2022» [15], while according to the Article 48 , increasing of the grant funding should not occur by reducing the institutional funding [2]. So, the enough level of the competitive research funding in Ukraine remain questionable.

The Law of Ukraine «On Higher Education» (LoHE) [1] was significantly changed in 2014 and it is also important for the R\&D policy and management. According to the LoHE, among the main objectives of higher education institutions is «obtaining competitive scientific and applied results» (Article 65). But the LoHE does not contain any obligations to obtain high scientific results for basic university workers. Thus, according to the Article 54 [1], professor and associate professor titles «assigned to persons who professionally engaged in scientific-pedagogical or artistic activities», and the title «senior researcher» assigned to persons who «professionally engaged in scientific or scientific-technical activities». The only fact regard to them, that as the scientists by the definitions, they obtain (in principle) scientific results, but without any obligations and clarifications. 
According to the typical contract [10], a university rector should provide high performance scientific, technical and innovation activities, competitive scientific and applied results and their implementation.

The idea to create Ukrainian research universities found its reflection in the new LoHE, where the Article 30 «Research university» [1], among other, contains requirements: the research university should provide scientific-educational activity at a world level, should have an enough number of publications in international refereed journals belonging to recognized international scientometric databases.

It is important to define indicators of scientific publications, which used as an essential component for obtaining D\&T. To defend the doctor of science thesis, there must be at least 20 publications, among of which at least four publications are in periodicals, indexed by international scientometric databases [5]. In order to obtain a candidate of science (or a $\mathrm{PhD}$ ) degree, at least 5 publications are needed, among them at least one in journals indexed in international scientometric databases. Scientific degrees of the doctor of science and candidate of science are conferred to persons «who have significant achievements in a certain field of science» according to the «Order on conferment of scientific degrees» [9]. The thesis should contain «scientifically justified results». The doctoral dissertation should solve an «important scientific or scientific-applied problem».

According to the legislation [6], the academic title of a professor can be assigned to a scientist, if one of the indicators of his/her activity is at least three articles in periodicals indexed in Scopus or Web of Science, which published after the defense of the doctor of science thesis. The academic title of an associate professor or a senior researcher can be assigned if the scientist has at least two publications in Scopus or Web of Science after obtaining the degree.

It should be noted [8] that according to the rules of Ukrainian science and higher education system, for scientists often is more optimal to obtain D\&T, than to produce high quality scientific knowledge. There are essential needs in D\&T for scientific-pedagogical workers in order to obtain license on education activity, especially to prepare graduate students. As the Article 28 of LoSSTA points out [2], D\&T are needed for a scientific worker as a qualification requirement for appointment to the posts. But there are no high requirements to $R \& D$ excellence or performance of lecturers in order to realize education in university. According to the Annex 12 to the License Conditions [11], only one article per five years in journals of Scopus and Web of Science is need for every scientific-pedagogical worker in order to realize education activity in university.

Our studies [8] and the Table 1 showed that creation of high quality scientific knowledge and obtainment of D\&T in Ukraine should be seen as not so strongly connected. There are strong needs of D\&T: (i) in order to occupy positions in the academic hierarchy, and (ii) in order to meet the requirements of education activity licensing [11].

In addition, the Ukrainian system of scientific publications is not homogenous and significant part of the journals doesn't use strong requirements to the scientific 
quality of the articles and qualitative peer review. According to the rules [4], an edition may be included to the «List of scientific professional editions of Ukraine» if its editorial board have «at least six doctors from the relevant field of science». Also a general requirement is the provision of an internal review of papers by the editorial board and the organization of an external review. However, the second requirement is not used as strong. It proved by the fact, that according to Scimago [23] only 40 Ukrainian editions fulfilled the demands of Scopus. Ukrainian scientists «must publish the results» (Article 6 of the LoSSTA [2]), but it is not determined anywhere that scientific publications should have (some or enough) citations.

As a result, there are no confirmations of focusing the Ukrainian science legislation on high quality of R\&D results, on excellence and performance. There are no principles, requirements and tasks of the state scientific policy in the LoSSTA to create high quality knowledge in accordance to the world standards of excellence and performance. The LoSSTA and LoHE articles are not contain direct norms of $R \& D$ quality as the requirements for scientists, scientific workers and scientific-pedagogical workers.

Discussion and conclusions. Our study shows that the requirements of «research excellence» and «excellence for innovations» [15] mainly absent in Ukrainian legislation, but they also have no systemic context in order to be realized. Either way, this correlates with fairly low R\&D results in comparison with many countries, which have a similar scientific culture and technological ambitions. Sometimes the legislation used the notions of «publications in scientometric databases» or «publications in journals of Scopus and Web of Science» as the equivalents of research and knowledge quality. However, the mostly well-defined forms are not knowledge and publications, but the D\&T. Their obtainment is not only the «State recognition of scientist's qualification» [2], but a key to social and professional positions. This is a weakness of Ukrainian $R \& D$ legislation if the scientific degrees and academic titles use as the symbols of scientific merit, but ones less present the research results of world-class and excellence for innovations, than social status and academic qualification, where the latter is not always an ability «to create».

Certainly, the legislation should not define norms, how much «knowledge» and «understanding» could be created or obtained by a scientist annually. Also, the legislative documents should not define, how many high quality publications and their citations should have a scientific or scientific-pedagogical worker. However, it is of great importance to define the demands for individual research attestation (assessment) in order to rank scientists in accordance to their scientific results and to stimulate their R\&D excellence and high performance, and use assessment as a tool for competition. It should be noted, the absence of such assessment is also weakness of Ukrainian R\&D legislation.

The study of the legislation shows that in order to obtain D\&T used the norms of results, which defined quite clearly by formal indicators of publications, but sufficiently blurred in epistemological sense. The number of publications, defined 
by legislation as minimal in order to obtain degrees of candidate $(\mathrm{PhD})$ and doctor of science and titles of docent (assistant professor) and professor, should be only five publications in Scopus or Web of Science and five ones in other scientometric databases. So, the high social status of scientist in Ukraine may «cost» only ten publications of ordinary quality and with co-authors. This could be a factor of aims and values deformation towards reducing requirements for knowledge quality and research performance. The factor of possible deformation could be compensated or realized by the R\&D management and the study of scientific activity at Ukrainian universities showed both types of examples.

It should be noted, that a part of the Ukrainian science legislation represents the need to provide mechanisms for ensuring a livelihood of scientists in context of the lack of funding. But the need to increase the funding is not connects in the legislation with objectives to rise the R\&D quality and performance.

Our previous study [8] showed that the possibility to obtain the D\&T was realized differently for scientific subject areas, but this is also question for our further research.

Should the requirements of «research excellence» and «excellence for innovations» be presented in Ukrainian legislation on Science? I could say «yes», if research quality and high performance will be defined as requirements to the aims, principles, criteria an tasks of $R \& D$ policy and management and the main obligations of all scientific, scientific-technical and scientific-pedagogical workers. This also regards to demands of novelty and justifiability of knowledge for Ukrainian journals publications, which could be defined as a scientific. The notions of research results quality, excellence and performance should be defined as the main requirement for attestation of scientists, desirably in accordance with the criteria of Research Assessment Exercises [17] of developed countries. It may be fruitful to use the approaches of the «Stairway to excellence» [18], the RRI [29] and performance based research funding.

It is very important for Ukrainian Science and Higher education to change the approach to obtain and to use the D\&T. If ones would not rigorously represent the high quality of research and obtained knowledge, they should not substitute more cognitive and innovative criteria. It should be defined in legislation, that they are not the criteria for operational R\&D management, but the elements of social status, obtained in past.

The new results of the study, that are partially confirmed, could be presented by the following propositions.

1. Epistemological incomparability and incommensurability of theories, the appraisal problem, the lack of opportunities to get the best knowledge, the lack of the best research method and incomparability of research assessment criteria could be presented as the research management problem, which defined as inability to make the best R\&D management actions.

2. The study shows that, due to imperfection of the legislation, the permanent obtainment of high quality knowledge by scientists may be less profitable than 
having D\&T in order to hold positions, receive wages and pensions, to have other benefits.

3. The study presents an example that the need for useful knowledge in «transition» countries under certain conditions could be weakened by the needs to seek mechanisms for ensuring the livelihood of scientists, if the R\&D results of high quality are not guarantee this

\section{REFERENCES}

1. Zakon Ukrainy «Pro vyshchu osvitu» [The Law of Ukraine «On higher education»]. Retrieved from http://zakon5.rada.gov.ua/laws/show/1556--18/page2 [in Ukrainian].

2. Zakon Ukrainy «Pro naukovu i naukovo-Tekhnichnu diialnist» [The Law of Ukraine «On scientific and scientific-technical activity»]. Retrieved from http://zakon3.rada.gov.ua/laws/ show/848-19 [in Ukrainian].

3. Illiashenko, S.M., \& Illiashenko, N.S. (2016). Perspecktyvu i zahrozy chetvertoi promyslovoi revoliutsii ta yikh urakhuvannia pry vybori stratehii innovatsiinoho zrostannia [Opportunities and threats of the fourth industrial revolution and their reflection in the selection of innovative growth strategies] Marketynh i menedzhment innovatsii - Marketing and Management of Innovations, 1, 11-21. Retrieved from http://mmi.fem.sumdu.edu.ua/journals/ 2016/1/11-21 [in Ukrainian].

4. Nakaz Ministerstva osvity i nauky, molodi ta sportu Ukrainy «Pro zatverdzhennia Poriadku formuvannia Pereliku naukovyrh fakhovykh vydan Ukrainy» [Order of Ministry of Education and Science, Youth and Sports of Ukraine «On approval of the Order of forming the List of scientific professional periodical editions of Ukraine»], adopted 17.10.2012, No 1111. Retrieved from http://zakon5.rada.gov.ua/laws/show/z1850-12 [in Ukrainian].

5. Nakaz Ministerstva osvity i nauky, molodi ta sportu Ukrainy «Pro opublikuvannia rezultativ dysertatsii na zdobuttia naukovykh stupeniv doktora nauk I kandydata nauk» [Order of the Ministry of Education and Science, Youth and Sports of Ukraine «On publication the results of the thesis for getting the scientific degree of doctor and candidate of sciences»], adopted 17.10.2012, No 1112. Retrieved from http://zakon2.rada.gov.ua/laws/show/z1851-12 [in Ukrainian].

6. Nakaz Ministerstva osvity i nauky Ukrainy «Pro zatverdzhennia Poriadku prysvoiennia vchenykh zvan naukovym I naukovo-pedahohichnum pratsivnykam» [Order of Ministry of Education and Science of Ukraine «On approval of the Order on assignment of academic titles to scientific and scientific-pedagogical workers»], adopted 14.01.2016, No 13. Retrieved from http://zakon2.rada.gov.ua/laws/show/z0183-16 [in Ukrainian].

7. Natsionalna dopovid pro stan I perspektyvy rozvytku osvity v Ukraini [National report on the state and prospects of education development in Ukraine] (2016). National Academy of Pedagogical Sciences of Ukraine; V.H. Kremen (ed.). Kyiv: Pedahohichna dumka [in Ukrainian].

8. Porev, S.M., \& Sandyga, I.V. (2016). Shliakh nauky universytetu [The Way of University Science]. Kyiv: Khimdzhest [in Ukrainian].

9. Postanova Kabinetu Ministriv Ukrainy «Pro zatverdzhennia Poriadku prysudzhennia naukovykh stupeniv» [Resolution of the Cabinet of Ministers of Ukraine «On approving of the Order on conferment of scientific degrees»], adopted 24.07.2013, No 567. Retrieved from http://zakon2.rada.gov.ua/laws/show/567-2013-\%D0\%BF [in Ukrainian].

10. Postanova Kabinetu Ministriv Ukrainy «Deiaki pytannia realizatsii statti 42 Zakonu Ukrainy «Pro vyshchu osvity» [Resolution of the Cabinet of Ministers of Ukraine «Some aspects of the implementation of Article 42 of the Law of Ukraine «On Higher Education»], adopted 05.12.2014, No 726. Retrieved from http://zakon3.rada.gov.ua/laws/show/726-2014$\%$ D0\% BF [in Ukrainian]. 
11. Postanova Kabinetu Ministriv Ukrainy «Pro zatverdzhennia Litsenziinukh umov provadzhennia osvitnoi diialnosti zakladiv osvity» [Resolution of the Cabinet of Ministers of Ukraine «On approval of the Licensing conditions for conducting educational activities of educational institutions»], adopted 30.12.2015, No 1187. Retrieved from http://zakon3.rada.gov.ua/laws/show/1187-2015-\%D0\%BF [in Ukrainian].

12. Postanova Kabinetu Ministriv Ukrainy «Deiaki pytannia obrannia ta pryznachennia kerivnyka derzhavnoi naukovoi ustanovy» [Resolution of the Cabinet of Ministers of Ukraine «Some aspects of the election and appointment of the manager of state scientific institution»], adopted 14.12.2016, No 998. Retrieved from http://zakon2.rada.gov.ua/laws/show/998-2016$\% \mathrm{D} 0 \% \mathrm{BF} /$ paran10\#n10 [in Ukrainian].

13. Bornmann, L. \& Daniel, H.-D. (2008). What do citation counts measure? A review of studies on citing behavior. Journal of Documentation, 64 (1), 45-80.

14. Chang, R. (1997). Incommensurability, Incomparability, and Practical Reason. Cambridge MA: Harvard University Press.

15. Chang, H. (2016). Peer review of the Ukrainian research and innovation system (Horizon 2020 Policy Support Facility). Luxembourg: Publications Office of the EU.

16. European Union. (2011). The analysis of the legislation of Ukraine in the sphere of research, developments and innovation activity and suggestions for amendments for legislation (Project «Enhance Innovation Strategies, Policies and Regulation in Ukraine»). Kyiv: Feniks.

17. Hicks, D. (2011). Performance-based university research funding systems. Research Policy, 41(2), 251-261. doi:10.1016/j.respol.2011.09.007

18. Klincewicz, K. (2015). Stairway to Excellence Country Report: POLAND. (European Commission, JRC Science and Policy Report, Ed.: N. Harrap). Luxembourg: Publications Office of the EU.

19. Kuhn, T. S. (1982). Commensurability, Comparability, Communicability. Proceedings of the Biennial Meeting of the Philosophy of Science Association, 2: Symp. and Invited Papers, 669-688.

20. Lakatos, I. (1978). The methodology of scientific research programmes. Philosophical Papers, Vol. I, J.Worral \& G. Currie, (eds.). Cambridge: Cambridge University Press.

21. Nowotny, H., Scott, P. \& Gibbons, M. (2003). Introduction: 'Mode 2' Revisited: the New Production of Knowledge. Minerva, 41(3), 179-194.

22. Rip, A. (2014). The past and future of RRI. Life Sciences, Society and Policy, 10 (article 17). 15.

23. SCImago Journal \& Country Rank. SCImago Research Group. Retrieved from http://www. scimagojr.com/

24. Schuch, K., Weiss, G., Buesel, K. \& Brugner, P. (2016). Ukrainian Research and Innovation System. Background Report. Luxembourg: Publications Office of the European Union.

25. Tijssen, R. J. W. (2003). Scoreboards of research excellence. Research Evaluation, 12(2), 91-103.

26. Turri, J. (2012). Is knowledge justified true belief? Synthese, 184(3), 247-259.

27. UNESCO Institute for Statistics, UIS online database. Retrieved from http://stats.uis. unesco.org

28. United Nations. (2013). Innovation Performance Review of Ukraine (Economic Commission for Europe). Geneva, Switzerland: United Nations.

29. Von Schomberg, R. (2013). A vision of responsible innovation. In R. Owen, M. Heintz \& J. Bessant (eds.), Responsible Innovation: Managing the Responsible Emergence of Science and Innovation in Society (pp. 51-74). London: John Wiley \& Sons.

30. Yegorov, I. (2012). ERAWATCH country reports 2012: Ukraine (ERAWATCH Network STEPS Centre of the NASU). ERAWATCH Network.

Received 11.10.2017 
C.M. Порев, кандидат технічних наук, завідувач лабораторії, Інститут магнетизму НАН і МОН України, e-mail: sn_porev@ukr.net

\section{ШО ЗАПРОПОНОВАНО УКРАЇНСЬКИМ ЗАКОНОДАВСТВОМ МЕНЕДЖМЕНТУ ДЛЯ ЯКОСТІ ДОСЛІДЖЕНЬ?}

Стаття містить дослідження законодавчих документів України з точки зору їх впливу на якість, досконалість і продуктивність досліджень. Проблему менеджменту досліджень визначено як обмеження на використання прямого менеджменту досліджень та причину застосування непрямих критеріїв. Дослідження показує, що цілі, принципи і вимоги до якості та продуктивності досліджень в основному відсутні в законодавстві України і не мають системного контексту для реалізації. Відзначено, що використання наукових ступенів і вчених звань як критеріїв якості, досконалості та продуктивності досліджень є чинником слабкості політики, оскільки вони в основному відображають соціальний статус і наукову кваліфікацію. Іншою слабкою позицією у законодавстві $є$ відсутність вимог до оцінювання досліджень окремих вчених з метою стимулювання якості досліджень і конкуренції в науковому середовищі. Основним результатом є те, що соціально-економічні перетворення можуть зашкодити єдності наукової політики, законодавства та менеджменту і змінити цінності когнітивної та творчої діяльності наукової спільноти.

Ключові слова: менеджмент досліджень, створення знань, законодавство науки, бібліометричні показники, наукові ступені, вчені звання, якість, досконалість, продуктивність.

C.Н. Порев, кандидат технических наук, заведующий лабораторией,

Институт магнетизма НАН и МОН Украины,

e-mail: sn_porev@ukr.net

\section{ЧТО ПРЕДЛОЖЕНО УКРАИНСКИМ ЗАКОНОДАТЕЛЬСТВОМ МЕНЕДЖМЕНТУ ДЛЯ КАЧЕСТВА ИССЛЕДОВАНИЙ?}

Статья содержит исследование законодательных документов Украины с точки зрения их влияния на повышение качества, совершенства и производительности исследований. Проблема менеджмента исследований определена как ограничение на использование прямого менеджмента исследований и причина применения косвенных критериев. Исследование показывает, что цели, принципы и требования к качеству, совершенству и производительности исследований в основном отсутствуют в законодательстве Украины и не имеют системного контекста для реализации. Отмечено, что использование научных степеней и ученых званий в качестве критериев качества, совершенства и производительности исследований является фактором слабости политики, поскольку они в основном отражают социальный статус и научную квалификацию. Другой слабой позицией в законодательстве Украины является отсутствие требований к оценке исследований отдельных ученых с целью стимулирования качества исследований и конкуренции в научной среде. Основным результатом является то, что социально-экономические преобразования могут повредить единству научной политики, законодательства и менеджмента и изменить ценности когнитивной и творческой деятельности научного сообщества.

Ключевые слова: менеджмент исследований, создание знаний, законодательство науки, библиометрические показатели, научные степени, ученые звания, качество, совершенство, производительность. 